NBER WORKING PAPER SERIES

\title{
DO A FIRM'S EQUITY RETURNS \\ REFLECT THE RISK OF ITS PENSION PLANS?
}

\author{
Li Jin \\ Robert Merton \\ Zvi Bodie \\ Working Paper 10650 \\ http://www.nber.org/papers/w10650 \\ NATIONAL BUREAU OF ECONOMIC RESEARCH \\ 1050 Massachusetts Avenue \\ Cambridge, MA 02138
}

August 2004

We thank Anna Yu, Alvaro Vivanco and especially Jason Oh for excellent research assistance, and the Department of Research at Harvard Business School, especially Sarah Woolverton, for help in obtaining data used in this paper. We benefited greatly from discussions with Lisa Meulbroek, Akiko Mitsui and Mitchell Peterson. The views expressed herein are those of the author(s) and not necessarily those of the National Bureau of Economic Research.

(C)2004 by Li Jin, Robert Merton, and Zvi Bodie. All rights reserved. Short sections of text, not to exceed two paragraphs, may be quoted without explicit permission provided that full credit, including (C notice, is given to the source. 
Do a Firm's Equity Returns Reflect the Risk of Its Pension Plan?

Li Jin, Robert Merton, and Zvi Bodie

NBER Working Paper No. 10650

August 2004

JEL No. G14, G23, G31

\section{ABSTRACT}

This paper examines the empirical question of whether systematic equity risk of U.S. firms as measured by beta from the Capital Asset Pricing Model reflects the risk of their pension plans. There are a number of reasons to suspect that it might not. Chief among them is the opaque set of accounting rules used to report pension assets, liabilities, and expenses. Pension plan assets and liabilities are off-balance sheet, and are often viewed as segregated from the rest of the firm, with its own trustees. Pension accounting rules are complicated. Furthermore, the role of Pension Benefit Guaranty Corporation further clouds the real relation between pension plan risk and firm equity risk.

The empirical findings in this paper are consistent with the hypothesis that equity risk does reflect the risk of the firm's pension plan despite arcane accounting rules for pensions. This finding is consistent with informational efficiency of the capital markets. It also has implications for corporate finance practice in the determination of the cost of capital for capital budgeting. Standard procedure uses de-leveraged equity return betas to infer the cost of capital for operating assets. But the deleveraged betas are not adjusted for the risk of the pension assets and liabilities. Failure to make this adjustment will typically bias upwards estimates of the discount rate for capital budgeting. The magnitude of the bias is shown here to be large for a number of well-known U.S. companies. This bias can result in positive net-present-value projects being rejected.

\begin{tabular}{|c|c|c|}
\hline $\begin{array}{l}\text { Li Jin } \\
\text { Harvard Business School } \\
\text { ljin@hbs.edu }\end{array}$ & $\begin{array}{l}\text { Robert C. Merton } \\
\text { Graduate School of Business } \\
\text { Harvard University } \\
\text { Morgan } 397 \\
\text { Soldiers Field Road } \\
\text { Boston, MA } 02163 \\
\text { and NBER } \\
\text { rmerton } @ \text { hbs.edu }\end{array}$ & $\begin{array}{l}\text { Zvi Bodie } \\
\text { Boston University } \\
\text { School of Management } \\
\text { zbodie@bu.edu }\end{array}$ \\
\hline
\end{tabular}




\section{Introduction}

In this paper, we examine the empirical question of whether real-world equity returns reflect the risk of corporate pension plans. We focus on the systematic risk of the firm and use beta from the Sharpe (1964) Capital Asset Pricing Model (CAPM) as the measure of such risk ${ }^{1}$.

There are many reasons why pension risk might not be reflected in equity returns. Pension plan assets and liabilities are off-balance sheet, and are often viewed as segregated from the rest of the firm. Pension plans indeed have their own trustees, and pension accounting rules are complicated. Furthermore, the role of the Pension Benefit Guaranty Corporation (PBGC) as guarantor of corporate pension benefits to employees complicates the actual relation between the risk of the pension plan and the risk of the firm equity.

There is a substantial literature in economics and finance studying "value transparency", or whether pension assets and pension liabilities affect the market valuation of firms. Representative papers include Oldfield (1977), Feldstein and Seligman (1981), Feldstein and Morck (1983), Bodie et al. (1987), Bulow et al. (1987) and Bodie and Papke (1992). These papers provide considerable empirical evidence that the equity market valuation of firms takes into account the difference between the value of pension plan assets and its liabilities, i.e., the pension surplus or deficit (if that difference is negative). Carroll and Niehaus (1998) confirm those findings in a parallel test of debt market recognition of the value of the pension surplus or deficit, by empirically examining the positive relation between funding of defined-benefit pension funds and debt ratings. Furthermore, in both equity and debt markets, there seems to be an asymmetric pattern in the impact of changes in pensions assets and liabilities on the market value of the firm and on debt ratings: while each dollar increase in liabilities lowers the market value of the firm by about a dollar, an equal increase in pension assets raises the firm's market value by less than a dollar. Similarly, a pension deficit reduces debt ratings by more than the same size pension surplus increases debt ratings. This is consistent with the view that, while an

\footnotetext{
${ }^{1}$ Although the explicit measure of systematic risk used here is in the context of the CAPM, the same approach can be applied to "multiple beta" asset pricing models, such as the Fama-French Three-Factor Model (1996), the Ross (1976) Arbitrage Pricing Theory, and the Intertemporal CAPM (Merton, 1992, Chapter 15). We are confident that the core empirical findings given here for the CAPM will remain robust with respect to these alternative specifications of systematic risk.
} 
under-funded pension liability should be fully reflected as a corporate liability, over-funded pension assets are not entirely a corporate asset, due to the difficulty of converting an overfunded pension plan's assets into unemcumbered corporate assets.

However, there has been almost no analysis in the literature, either theoretical or empirical, about how the risk level of a defined-benefit pension plan affects the risk of the market value of the firm. As we shall see, value transparency does not necessarily imply risk transparency. The former is a static measure, whereas the latter is a dynamic measure. To our knowledge, our paper is the first to focus on dynamic measurement by testing whether pension-plan systematic risk is reflected in firm equity risk.

Since estimates of beta play a pivotal role in performance evaluation and in the estimated cost of capital calculation, accurate estimation of beta is crucial. The question we address therefore has important implications for the correct calculation of operating-asset beta and tests of market efficiency, regardless of the direction of the answer.

i) On the one hand, if pension risk is not accurately reflected in the firm's equity beta (which implies that the market is informationally inefficient) then, standard analysis will usually underestimate the true systematic risk of the firm. This underestimation of risk may lead to the appearance of superior corporate performance on a riskadjusted basis and that in turn would lead to a pattern of overvaluation of the firm.

ii) On the other hand, if the firm's equity beta does accurately reflect its pension plan risk, it can have significant implication for corporate finance in estimating a firm's cost of capital. The standard methodology for calculating the cost of capital treats it as a weighted average of the cost of equity and the after-tax cost of debt (which is the pre-tax cost of debt adjusted for the tax shield generate by the corporate debt) ${ }^{2}$. Such calculation implicitly neglects the pension plan, or, it assumes that the pension assets/liabilities have just the same risk characteristics as the operating asset and therefore do not need to be counted separately. The plain facts are that pension plan

\footnotetext{
${ }^{2}$ See, for examples, Brealey and Myers (2002), Copeland and Weston (1992), Ross, Westerfield and Jaffe (2002) and Van Horne and Wachowicz (1995).
} 
assets and liabilities are substantial for many firms, and they would only coincidentally have the same risk characteristics as the operating assets. As will be demonstrated, large estimation biases for the firms' operating betas can exist in such cases.

The paper is organized into three sections: (1) a theory section in which we derive the theoretical asset beta for the firm's operating asset as a function of the firm's equity beta, pension-asset beta, debt and pension liability beta. From this, we derive the specification errors in the estimation of the operating asset beta if pension assets and liabilities are completely ignored, and if the value of the pension plan is correctly taken into account but not its risk. For a selected sample of firms we show as an empirical matter that the resulting overstatement of the cost of capital can be substantial; (2) an empirical section in which we use the theoretical specifications to study U.S. pension-plan risk using time series data from 1993 to 1998 for companies filing ERISA form 5500. This period was prior to the sharp and sustained decline in the stock market, particularly NASDAQ, in 2000-2002, and the subsequent media spotlight on pension-plan risk. We find that the market risk of the firm's equity reflects the risk level of the pension plan; (3) a robustness section to examine the sensitivity of test findings to our assumptions. We find our results to be robust.

\section{The Theory ${ }^{3}$}

In the United States, when a company sponsors a defined-benefit pension plan, the plan's assets and liabilities, although segregated, are, in economic terms, assets and liabilities of the company. The company and its pension plan as a consolidated entity have three groups with a claim on the firm's total assets: (1) the employees,--retired and active, (2) the investors -- shareholders and creditors, and (3) the government, through corporate taxes and corporate pension benefit guarantees. The employees' claim on the retirement benefits, the pension liability, is a debt-like liability of the firm, secured by the pension assets as specific collateral.

\footnotetext{
${ }^{3}$ This section is based on Merton (2002).
} 
Ignoring the effect of taxes and the PBGC, we derive the relations between pension-plan risk and firm equity risk, and discuss how the firm's operating-asset risk can be correctly estimated from the pension-plan risk and observed equity risk. We then derive the structure of estimation specification errors in measuring firm operating-asset risk when pension risk is accounted for improperly. In doing so, we analyze two circumstances: 1) that the entire pension plan, assets and liabilities, is totally neglected in the estimation of operating-asset risk; 2) the values of pension assets and liabilities are correctly taken into account, but the risks of plan assets and liabilities are not. We then discuss the effect of corporate tax and the role of PBGC.

\subsection{The estimation of operating-asset risk from pension and stock market data}

Consider the case where there are no taxes and we have no Pension Benefit Guaranty Corporation.

Define:

OA as the value of operating assets, E as the value of Equity, D as the value of Debt, PA as the value of pension assets, PL as the value of pension liabilities, $\mathrm{S}=\mathrm{PA}-\mathrm{PL}$ as pension surplus, $\mathrm{L}=$ $\mathrm{D} / \mathrm{E}$ as the leverage ratio. By the balance sheet identity we have that:

$$
\text { Assets }=O A+P A=E+D+P L=\text { Liabilities }
$$

We examine three possible cases:

Correct Case: The calculation of operating-asset risk correctly incorporates both the value and the risk characteristic of the pension plan;

The beta of operating assets, $\beta_{O A}$, when both the pension value and pension risk are correctly taken into account is:

$$
\begin{aligned}
& \beta_{O A}=\frac{E}{O A} \beta_{E}+\frac{D}{O A} \beta_{D}-\left[\frac{P A}{O A} \beta_{P A}-\frac{P L}{O A} \beta_{P L}\right] \\
& =\frac{E}{O A}\left(\beta_{E}+\beta_{D}\right)+\frac{D-E}{O A} \beta_{D}-\frac{P A}{O A}\left(\beta_{P A}-\beta_{P L}\right)-\frac{S}{O A} \beta_{P L}
\end{aligned}
$$


Error Case 1: The calculation of operating-asset risk ignores the pension plan, both its value and its risk ${ }^{4}$.

If both the value and the risk of the pension plan are ignored, then the estimated operating-asset beta becomes

$$
\hat{\hat{\beta}}_{O A}=\frac{D}{E+D} \beta_{D}+\frac{E}{E+D} \beta_{E}
$$

Subtracting (1) from (2), we have that the resulting estimation specification error, defined as $\hat{\hat{\varepsilon}}_{O A}=\hat{\hat{\beta}}_{O A}-\beta_{O A}$, is:

$$
\hat{\hat{\varepsilon}}_{O A}=\frac{P A}{O \hat{A}}\left(\beta_{P A}-\beta_{P L}\right)-\frac{S}{O \hat{A}}\left[\beta_{O A}-\beta_{P L}\right]
$$

where $O \hat{A}=O A+S$.

Proof: see appendix.

By inspection of (3), a sufficient condition for $\hat{\hat{\varepsilon}}_{O A} \geq 0$ is $\beta_{P A} \geq \beta_{P L}, \beta_{O A} \geq \beta_{P L}$, and, $S \leq 0$.

These conditions are often satisfied in reality, indicating that there is specification error on the estimate of the operating-asset beta, which generally has a positive bias, if one ignores the risk and value of defined-benefit pension plans.

Error Case 2: The calculation of risk includes the pension plan value, but neglects any difference in risk between pension assets and pension liabilities ${ }^{5}$.

If we assume that pension asset and pension liability risk are the same and equal to the risk of the debt of the firm: $\hat{\beta}_{P A}=\hat{\beta}_{P L}=\beta_{D}{ }^{6}$, then the risk of the operating assets is given by:

\footnotetext{
${ }^{4}$ The standard textbook treatments typically calculate the WACC as the weighted average cost of debt and equity, with no adjustment for pension risks. See examples cited in footnote 2.

${ }^{5}$ It recognizes the surplus or shortfall in pension-plan value, perhaps because it appears as a net entry on the firm's balance sheet but it treats that surplus or shortfall as having the same beta as debt.
} 


$$
\hat{\beta}_{O A}=\beta_{E} \frac{E}{O A}+\beta_{D} \frac{(D-S)}{O A}
$$

Thus, subtracting (1) from (4), the specification error in the estimated beta is given by:

$$
\hat{\varepsilon}_{O A}=\frac{P L}{O A}\left(\beta_{D}-\beta_{P L}\right)+\frac{P A}{O A}\left(\beta_{P A}-\beta_{D}\right)
$$

Proof: see appendix.

In practice, the risk levels of pension liabilities and firm debt are similar for firms with normal leverage ratios, whereas the portion of pension assets that are invested in equities will have significantly higher beta risk than the firm debt. Neglecting this higher pension asset risk will lead to a positive bias in the estimation of the beta of the operating assets.

The biases from ignoring the pension asset risk can be substantial. The biases from counting the value of the pension plan but ignoring the risk of pension plans can also be large. In Table 1.1. and Table 1.2. we underscore this point with four examples of well-known large firms.

[Insert Table 1.1 and Table 1.2 around here.]

In Table 1.2 we posit that the pension liability has the same beta as the firm's debt, both assumed to be 0.175 . We further posit that $60 \%$ of the pension fund is invested in the equity market and the rest are invested in debt with a beta of 0.175 , and thus the overall beta for pension assets is assumed to be 0.67 . This is a conservative estimate of the pension asset beta for typical firms. Indeed, the PBGC recommended that pension plans invest $60 \%-80 \%$ of the pension asset in equities ${ }^{7}$, and during the bull market of the 1990s many firms did just that.

Substituting these assumed beta values into equation (5), we get:

\footnotetext{
${ }^{6}$ Once the value of the pension plan is taken into account, some risk level has to be assigned to its assets and liabilities for the calculation of firm operating-asset risk. It is generally incorrect to assume that pension assets have the same risk as pension liabilities. If the debt of the firm is highly rated with a similar duration as the pension liabilities, it is reasonable to treat them as having the same systematic risk.

${ }^{7}$ For example, see Bodie (1996).
} 


$$
\hat{\varepsilon}_{O A}=(0.67-0.175) \frac{P A}{O A}=0.495 \frac{P A}{O A}
$$

By inspection of Table 1.1., three of the firms' plans are over-funded, and the fourth, Du Pont, has a small pension deficit. All four firms, however, have pension assets that are very large relative to their market capitalization. The correct estimates of operating-asset beta for these four firms are $0.16,0.45,0.35$ and 0.26 , respectively, but the flawed procedure that ignores the pension plan altogether produces estimates of operating-asset betas of $0.54,0.63,0.68,0.43$, respectively. The estimation errors are large, and the operating-asset betas are overstated by between $40 \%$ and $250 \%$. The last column shows that, when pension value but not pension risk is incorporated in the calculation, the resulting betas are still significantly different from their correct values.

Thus, standard cost-of-capital calculations, which do not distinguish between the operating-asset risk and pension-plan risks, can materially overestimate the discount rate for operating projects. For an equity risk premium of $7 \%$, and a risk free rate of $5 \%$, the correct cost of capital for the existing operating assets of Boeing is 6.09\%, but the standard approach yields $8.80 \%$, an overestimate of about 45\%. For DU PONT, EASTMAN KODAK, and TEXTRON, the correct cost of capital are $8.15 \%, 7.47 \%$, and $6.81 \%$, respectively, while the standard approach yields $9.44 \%, 9.75 \%$, and $7.98 \%$, respectively, for a $15 \%$ to $30 \%$ error.

\section{Effect of Corporate Taxes}

Now consider the effect of corporate taxes on the relation between the risk of the pension plan and the risk to investors in the firm. There is a considerable range in the theory of corporate finance about the effect of taxes on the valuation of a firm and thus, on the risk of the firm. The original controversy is focused on whether debt financing increases the total value of the firm relative to its value under all-equity financing. As shown by Miller (1977), the answer hinges on the complex interaction between corporate and personal taxation in a general model of capital market equilibrium. 
Black (1980) and Tepper (1981) examine the effect of corporate taxes on the valuation of corporate pension assets and liabilities. Under symmetric assumptions about contribution opportunities, tax payments and rebates, they conclude that a $\$ 1$ change in the pre-tax value of pension surplus (i.e., assets minus liabilities) causes $\$(1-t)$ change in the value of the firm where $t$ is the effective corporate tax rate. Thus, the government bears fraction $t$ of the pension-surplus risk through taxes.

Bulow, Morck and Summers (1987) revisit the question and conclude that depending on the extent to which the ceiling on pension fund contributions can be binding, the relation ranges from (1-t) to 1.0. Beyond the theoretical complexities, there are further empirical ones: the effective versus statutory tax rates for real-world firms vary considerably in cross-section and for the same firm over time. Accounting rules that govern how pension surplus is computed for determining contribution limitations currently have multi-year smoothing features. Thus, in the absence of individual firm tax-rate data, we make no adjustment for taxes in our test specification in Section 3.

\subsection{Effect of PBGC Insurance}

The PBGC covers any shortfall in funding for pension plans of bankrupt firms, in effect providing the plan participants with a put option on the pension fund collateral for their benefits ${ }^{8}$. The price charged for this PBGC insurance is not a function of either the credit quality of the plan sponsor or of the risk of the plan's assets. Thus, its premium for coverage is not equal to its fair market value. Distressed firms are charged less than the fair value and healthy firms are charged more ${ }^{9}$. Even if PBGC insurance were fairly priced, the insurance transfers part of the risk associated with the pension assets and liabilities from the corporate sponsor to the PBGC. PBGC insurance creates an incentive for distressed firms to underfund the pension plan and invest the plan in risky assets. Bodie et al (1985) find some empirical evidence of this effect. At the theoretical level, the existence of the PBGC introduces a complex non-linear relation between the value and risk of pension assets and liabilities and the risk of investor capital for

\footnotetext{
${ }^{8}$ There is a ceiling on benefits covered of $\$ 44,386$ per year per employee, for the year 2004 .

${ }^{9}$ The detailed procedures for setting pension premium can be found from the PBGC website, at http://www.pbgc.gov/publications/factshts/PREMFACT.htm.
} 
corporations that are in financial distress ${ }^{10}$. Partly for this reason, we focus in our empirical analysis on firms that are not in distress.

\section{Empirical Analysis}

In the preceding section we derive the risk relations among the firm's assets and liabilities when they are fully recognized by investors and measured at market prices. In this section we explore the question: do those relations hold in practice? We consider, as an empirical matter, the extent to which a company's pension funding status and asset mix are incorporated in the risk of its equity. Specifically we test the hypothesis that a higher pension-plan risk translates into a higher overall firm market risk, and we also try to estimate the magnitude of the pension risk-firm risk relation.

\subsection{Data and measurement of variables}

The data used in our study cover the period from 1993-1998. They come from three sourcesIRS Form 5500 filings, COMPUSTAT, and CRSP. The Form 5500 provides asset class information for each plan sponsored by a company. The assets are disaggregated into categories such as certificates of deposit, U.S. government securities, corporate debt instruments and common stocks and reported at market value. COMPUSTAT provides company-level data about total pension liabilities and other balance sheet and income statement variables reported by the firm. We match data from the two sources to create a merged company-level data set. ${ }^{11}$ COMPUSTAT data are created from company 10-K reports, which is released with a much shorter time lag than Form 5500 data. The COMPUSTAT data is also more widely used by market participants. CRSP data are used to calculate equity betas for the firms in our sample.

From these data, we compute the market risk exposure from the pension plan by making certain assumptions about the beta risk of various categories of assets and liabilities. Table 2 contains

\footnotetext{
${ }^{10}$ See Bodie (1996) for the discussion about the PBGC “pension put”.

11 The Form 5500 data tape is made available to the public with roughly a 2-year lag. Sponsors of any plan with more than 100 employees are required by law to file the form.
} 
the assumptions about beta for various asset classes that we use in computing the total risk of pension assets and pension liabilities. ${ }^{12}$

[Insert Table 2 around here]

From the firm's balance sheet identity we have that $E+D=O A+P A-P L$, the firm's invested capital, defined as debt plus equity, equals the value of operating assets plus the pension-plan surplus.

Define the capital-structure risk, i.e., the systematic risk borne by the equity and debt holders of the firm as $\beta_{E+D}=\beta_{E} \frac{E}{E+D}+\beta_{D} \frac{D}{E+D}$. It follows that: $\beta_{E+D}=\frac{\beta_{P A} P A}{E+D}-\frac{\beta_{P L} P L}{E+D}+\frac{\beta_{O A} O A}{E+D}$

Thus there is a one-to-one relation between the risk of the firm's capital structure, measured by the weighted average of equity and debt risk, and the net pension-plan risk, measured as $\beta_{\text {Pension }}=\frac{\beta_{P A} P A}{E+D}-\frac{\beta_{P L} P L}{E+D}$. Namely, we have that

$$
\beta_{E+D}=\beta_{\text {Pension }}+\frac{O A}{E+D} \beta_{O A}
$$

To estimate the equity betas, we use weekly data for one year (up to 52 observations). To make sure our beta estimate is meaningful, we eliminate stocks that have not been traded for more than 43 weeks during a year. Since we are using relatively higher frequency data, to adjust for nonsynchronous trading, we employ Dimson's (1979) adjustment with one lag and no leads to calculate the beta. To test robustness, we also examined different specifications of leads and lags and did not find a qualitative change in the results.

\footnotetext{
${ }^{12}$ These estimates of the beta risk for asset categories are drawn from a study done by Harvard Management Company to calculate the portfolio choices for the firm. The numbers are cited from Light (2001).
} 


\section{Restriction to non-distressed firms}

We restrict our attention to firms that are not in financial distress, for several reasons. First, for distressed firms, one must take into account the effect of the guarantee provided by the Pension Benefit Guarantee Corporation. Second, we do not have data on the market value of the debt of the firm, so we use the book value of debt as an approximation for market value. This proxy will work reasonably well when the firm is not in distress, since the market value of the debt typically does not deviate significantly from the book value of debt ${ }^{13}$. But this is not true for debt of firms in financial distress, which can sell at a discount to book value and often trades with an equitylike beta. Third, the betas of the debt and equity of firms in distress are nonlinear functions of the value of the firm ${ }^{14}$.

We use three empirical measures to identify the financially distressed firms: 1) return on investment as a measure of operating-business distress, 2) leverage as a measure of financial distress, and 3) book/market value as a combination measure of both types of distress. ${ }^{15}$ In each year in our sample, we rank all firms in the previous year by each measure of distress, and take the decile of firms with the most severe measure as distressed, and the rest as non-distressed. We subsequently run regressions for the next year only on firms that are not in distress in the previous year. Most of the tables in the body of the paper only report regression results using the book-market ratio as the measure of distress ${ }^{16}$. However, the full results, using all three measures of distress, are presented in the appendix.

\footnotetext{
${ }^{13}$ A caveat: even for non-distressed firms, interest-rate changes can cause significant changes in the value of fixedrate debt value. Indeed, the 0.175 estimate for the beta of debt used throughout the paper is primarily the result of estimated correlations between interest rate changes and equity returns during the sample period and not the risk of default. With the widespread use of interest-rate swaps by corporations, it is not easy to determine the effect of interest-rate changes on firm and equity values. We have nevertheless explored this effect and tried to adjust the book value of debt by the change in the market interest rate to better approximate the market value of debt. Such adjustments give results that are consistent with those reported in the paper, suggesting that the adjustment for bookmarket value difference in debt is not driving the results of the paper. Detailed results are available upon request.

${ }^{14}$ See Merton (1992), chapters 11, 12.

${ }^{15}$ Use of these measures as indicators for financial and operating-business distress can be found in Andrade and Kaplan (1998).

${ }^{16}$ We recognize that for the Fama-French (1992) model, book-to-market is a systematic risk factor, not necessarily associated only with distress. As discussed in Section 4.A, excluding or including this group in the firm sample does not affect our findings.
} 


\subsection{Test results and interpretation}

We fit the following time-series regression:

$$
\beta_{E+D}=a+\gamma \beta_{\text {Pension }}+\varepsilon
$$

Perhaps not surprisingly, pension liabilities exhibit strong serial correlation. In addition, firm pension asset allocation decisions also change slowly over time. This gives a justification that we could still run the regressions in the paper, even that some of the information from pension asset holdings might not be immediately revealed to all the market participants: most of the difference in pension asset risk is cross-sectional, rather than time-series, thus by observing the lagged pension asset allocation decision of a firm, one can infer with reasonable accuracy the current period pension risk profile ${ }^{17}$. To guard against cross-correlation and serial correlation, we employ the Fama and MacBeth (1973) methodology, and further adjust the t-statistics using the approach by Pontiff $(1996)^{18}$.

The regression coefficients and their t-statistics are reported in Table 3. The results indicate a positive relation between pension-plan risk and firm risk: one unit of pension risk increases the firm risk by 1.7-2.0 units. The relation is statistically significant, although the point estimates are larger than the theoretical value of 1.0 .

[Insert Table 3 around here.]

Consider now the further implicit assumption underlying the specification in (7). By inspection of equation (6), firm risk is affected by the risk of both pension assets and non-pension assets.

\footnotetext{
${ }^{17}$ As shown in Appendix A, it is not entirely clear when the public get information about pension positions, as some pension asset holding information might be released to the public rapidly. To the extent that insiders but not the general public know the current pension positions, our test of the relation between current period pension risk and current period capital structure risk would constitute a test of the strong form of efficient market hypothesis.

${ }^{18}$ Pontiff (1996) realizes that, in a setting of serious serial correlation, because the slope coefficients in the FamaMacBeth regressions are persistent through time, the Fama-MacBeth standard errors could still be biased downward. He proposes correcting for such bias by regression the time-series of the parameter estimates on an intercept term and modeling the residuals as an autoregressive process. As we have six years of data, we model the residuals as an AR(1). Changing the specification to AR(2) doesn't qualitatively affect the results in the paper.
} 
The regression specification in (7) gives an unbiased estimate of the impact of pension risk only if the omitted variable, non-pension operating-asset risk, is uncorrelated with the pension-asset risk. Such an assumption is clearly unfounded. Much of the risk in the pension fund comes from its equity holdings and these are of course highly correlated with non-pension asset risk of the firm. As another, more subtle source of correlation, some firm managements may take an integrated perspective in managing their firms’ pension and non-pension risk, causing pension and non-pension risk to potentially be correlated. We do not have a direct measure of the nonpension asset risk and so in an expanded specification, we substitute control variables as proxies for differences in the non-pension operating asset risks across the firms. Our choice of control variables is influenced by prior research identifying selected variables that are significant in the study of the impact of pension value on firm value. By using these variables in an expanded specification, we can also see if our significant findings in the univariate analysis of pensionfund risk recognition by the market in (7) is just a surrogate for the variables that were used in earlier studies to test whether pension plan value is recognized in a firm's stock price. As we shall see, that is not the case.

The list of control variables and the detailed procedure to construct them is in Table 4.

[Insert Table 4 around here.]

The results of the regression with control variables are listed in Table 5, which reports explicitly only the coefficient estimates and their significance for the pension-plan risk variable as in (7). The complete regression results, including coefficients for all control variables and using all three measures of financial distress, are in the appendix.

\section{[Insert Table 5 around here.]}

As can be seen, the coefficient on pension risk is smaller in magnitude, but still statistically very significant. Furthermore, the point estimate of the coefficient is not significantly different from 
the theoretically predicted $1.0^{19}$, if the market correctly incorporated pension-plan risk into its estimate of equity risk.

\section{Robustness Checks}

\section{A. Distressed firms}

As discussed, distressed firms are likely to have a distinctly different pattern than non-distressed firms. Thus we re-run the regression analysis specified in Table 5 with the distressed firms subsample. The results are reported in Table 6.

\section{[Insert Table 6 around here]}

Inspection of Table 6 shows that the relation between pension risk and firm risk is insignificant for these firms.

We also re-run the regressions of Table 5, with the full sample (both distressed and nondistressed firms). The results are in Table 7.

[Insert Table 7 around here.]

We see that even when the full sample is used, the relation between pension risk and firm risk is still significant and in the predicted direction. Thus, the a priori choice to exclude distressed firms does not change the core findings.

\footnotetext{
${ }^{19}$ We have also estimated the model with separate coefficients on pension asset risk and pension liability risk. We find that the pension asset risk has a positive impact on firm risk, and pension liability risk has a negative impact on firm risk. Both effects are statistically significant. Furthermore, the coefficient on pension asset risk is smaller than the coefficient on pension liability risk, mirroring the findings in the studies looking at the differential impacts on firm value of the level of pension assets versus pension liabilities. Our potential explanation for the larger weighting on pension liabilities than on assets is that the change in pension liabilities is strongly correlated with interest rate changes and the change in pension assets are strongly correlated with stock returns and the CAPM single-variable descriptor is not adequate to deal with it.
} 


\section{B. filtered tests}

One concern with the interpretation of our findings is that there are likely to be many firms that have negligible pension assets/liabilities compared with the firm assets. For these firms, we would expect that pension risk would not have a first-order impact on the overall firm risk, especially considering the various other factors that might affect the firm risk. Thus, including these observations in our regression analysis would not likely add information, and thus dilute the fit of the true relation we are attempting to estimate. With this in mind, we also run regressions which require either 1 ) that pension assets represent greater than a certain percentage

of the total firm book asset $\left(\frac{P A}{E+D}>\right.$ threshold $)$, or 2$)$ that the product of pension asset beta risk and PA/TA is greater than a specified threshold $\left(\frac{\beta_{P A} P A}{E+D}>\right.$ threshold $)$. We use threshold levels ranging from $2 \%$ to $20 \%$, and the results are qualitatively the same.

Table 8 reports the filtered test results for a 2 percent threshold with non-distressed firms selected by book-to-market ratio only. Other measures of distress give qualitatively similar results and are presented in the appendix.

[Insert Table 8 around here.]

Again, our test results support the hypothesis that market seems to react to the risk level of the pension plan as predicted: a higher pension risk will increase the total market risk of the firm asset, while a lower pension risk would decrease the asset market risk of the firms.

\section{Conclusion}

This paper focuses on an important but previously neglected area of corporate finance: namely the impact of off-balance-sheet and non-operating risks on the risk of a firm's equity and the bias it may induce in estimation of the firm's cost of capital for capital budgeting. The paper's specific focus is a corporation's defined-benefit pension plan, which for many firms is as large as 
the market capitalization of the firm sponsoring the plan. Current accounting rules for corporate pensions are complicated and opaque. We examine the potential biases that can be introduced in the market's perception of a company's equity risk by ignoring the risk of its pension assets and liabilities, and we perform empirical tests to determine whether such a bias exists in practice.

The central empirical finding of the paper is that the stock market seems to process the available pension information without bias despite the practical difficulties of deciphering corporate pension accounts. Using the best publicly available U.S. data, our regression tests indicate that equity betas of firms do appear to accurately reflect the betas of their pension assets and liabilities. That is good news for market efficiency of the capital markets.

The bad news is that standard cost-of-capital calculations used in corporate finance, which do not distinguish between the operating-asset risk and pension-plan risk, can greatly overestimate the discount rate for Net Present Value analysis of operating projects. When calculating a firm's operating cost of capital for use in performance measurement and in capital budgeting, the standard approach to estimation fails to take proper account of the pension plan sponsored by the firm. The resulting estimate of operating-asset beta and cost of capital are almost always too high. As we show in Table 1.2, for some well-known companies, the calculated cost of capital can be more than $40 \%$ higher than its true value. In such cases, capital projects with positive Net Present Value may be rejected by management.

In this paper, we have focused on just one non-operating risk item of the firm--- the company pension plan. There are other non-operating-asset-related risk exposures that might have a significant impact on the risk of a firm's equity and on the calculation of its cost of capital. A perhaps prosaic, but important one, especially for established hi-tech firms, is the net cash and marketable securities held by the firm. Off-balance sheet risks of the firm from derivatives and other significant contractual obligations including performance guarantees can potentially distort cost of capital estimates for its operating businesses. Empirical research on their actual impact remains a task for the future. 


\section{References}

Andrade, G., Kaplan, S., 1998. How costly is financial (not economic) distress? evidence from highly leveraged transactions that became distressed. Journal of Finance. 53 (5). 1443-93.

Black, F., 1976. The investment policy spectrum: individuals, endowment funds and pension funds. Financial Analyst Journal, 32 (1). 23-31.

Black, F., 1980. The tax consequences of long-run pension policy. Financial Analyst Journal, 36 (4). 21-28.

Bodie, Z., 1996. What the pension benefit guaranty corporation can learn from the federal savings and loan insurance corporation. Journal of Financial Services Research. 10 (1). 83-100.

Bodie, Z., Light, J., Morck, R. and Taggart, R., 1985. Corporate pension policy: an empirical investigation. Financial Analysts Journal, 41 (5). 10-16.

Bodie, Z., Light, J., Morck, R. and Taggart, R., 1987. Funding and asset allocation in corporate pension plans: an empirical investigation. In: Bodie, Z., Shoven, J. and Wise, D. (Ed.), Issues in Pension Economics. National Bureau of Economic Research Project Report Series, Chicago and London: University of Chicago Press, Chicago.

Bodie, Z., Papke, L., 1992. Pension fund finance. In: Bodie, Z. and Munnell, A. (Ed.), Pensions and the Economy, University of Pennsylvania Press, Philadelphia.

Brealey, R., Myers, S., 2002, Principles of Corporate Finance, Irwin/McGraw-Hill, New York City, New York.

Bulow, J., Morck, R. and Summers, L., 1987. How does the market value unfunded pension liabilities? In: Bodie, Z., Shoven, J. and Wise, D. (Ed.), Issues in Pension Economics. National 
Bureau of Economic Research Project Report Series, Chicago and London: University of Chicago Press.

Carroll, T., Niehaus, G., 1998. Pension plan funding and corporate debt ratings. Journal of Risk \& Insurance. 65 (3). 427-43.

Copeland, T. and Weston, J., 1992. Financial Theory and Corporate Policy, Addison-Wesley Publishing Company. New York City, New York.

Coronado, J., Sharpe, S., 2003. Valuing the earnings effect of defined benefit pension plans: did higher stock prices cause stock prices to rise? Federal Reserves Board Working paper.

Dimson, E., 1979. Risk measurement when shares are subject to infrequent trading. Journal of Financial Economics, 7 (2), 197-226.

Fama, E., MacBeth, J., 1973. Risk, return, and equilibrium: empirical tests. Journal of Political Economy. 81 (3). 607-36.

Fama, E., French, K., 1992. The cross-section of expected stock returns. Journal of Finance, 47 (2). 427-65.

Feldstein, M., Morck, R., 1983. Pension funding interest rate assumptions, and share prices. In: Bodie, Z. and Shoven, J. (Ed.), Financial Aspects of the United States Pension System, University of Chicago Press, Chicago.

Feldstein, M., Seligman, S., 1981. Pension funding, share prices, and national savings. Journal of Finance. 36 (4). 801-24.

Light, J., Harvard Management Company, 2001. Harvard Business School Case No. 9-201-129.

Merton, R., 1992. Continuous-Time Finance. Revised Edition, Basil Blackwell, Oxford, U.K. 
Merton, R., 2002. Financial engineering: the underlying discipline for financial innovation and risk management. Presentation at MIT Sloan School of Management.

Miller, M., 1977. Debt and Taxes. Journal of Finance, 32 (2). 261-75.

Oldfield, G., 1977. Financial aspects of the private pension system. Journal of Money, Credit \& Banking. 9 (1). 48-54.

Papke, L., 1999. Are 401(k) plans replacing other employer-provided pensions? evidence from panel data. Journal of Human Resources. 34 (2). 346-68.

Pontiff, J., 1996, Costly arbitrage: evidence from closed-end funds. Quarterly Journal of Economics, 111 (4). 1135-1151.

Ross, S., 1976. The arbitrage theory of capital asset pricing. Journal of Economic Theory. 13 (3). 341-60.

Ross, S., Westerfield, R. and Jaffe, J., 2002. Corporate Finance, McGraw-Hill/Irwin, New York City, New York.

Sharpe, W., 1964. Capital Asset Prices: A theory of market equilibrium under conditions of risk. Journal of Finance 19 (3). 425-442.

Tepper, I., 1981. Taxation and corporate pension policy. Journal of Finance. 36 (1). 1-13.

Van Horne, J., Wachowicz, J., 1995. Fundamentals of Financial Management, Prentice Hall, Englewood Cliffs, New Jersey. 
Table 1.1. Selected Company Balance Sheet Information for 2001

\begin{tabular}{|c|c|c|c|c|c|c|}
\hline Company & $\begin{array}{l}\text { Pension } \\
\text { Asset } \\
(\$ M M)\end{array}$ & $\begin{array}{l}\text { Pension } \\
\text { Liability } \\
\text { (\$MM) }\end{array}$ & $\begin{array}{l}\text { Pension } \\
\text { Surplus } \\
\text { (shortfall) } \\
(\$ M M)\end{array}$ & $\begin{array}{l}\text { Mkt } \\
\text { Cap. } \\
\text { Of } \\
\text { Equity } \\
(\$ M M)\end{array}$ & $\begin{array}{l}\text { Book } \\
\text { Value of } \\
\text { Debt } \\
(\$ M M)\end{array}$ & $\begin{array}{l}\text { Operating } \\
\text { Asset (= } \\
\text { E+ D - } \\
\text { PA + PL) } \\
(\$ M M)\end{array}$ \\
\hline BOEING & 33,810 & 32,693 & 1,117 & 30,942 & 12,265 & 42,090 \\
\hline DU PONT & 17,923 & 18,769 & (846) & 42,593 & 6,814 & 50,253 \\
\hline $\begin{array}{l}\text { EASTMAN } \\
\text { KODAK }\end{array}$ & 7,942 & 7,439 & 503 & 8,562 & 3,200 & 11,259 \\
\hline TEXTRON & 4,480 & 3,908 & 572 & 5,856 & 7,149 & 12,433 \\
\hline
\end{tabular}

Note: Pension Asset and Pension Liability and Market Cap information are as estimated based on the Global Equity Research Report published by UBS Warburg, September 19, 2002. Beta of equity are estimated using CAPM, using data on three year monthly stock returns, obtained from CRSP, and by using the value-weighted return on all stocks on NYSE/AMEX/NADDAQ as the proxy for the market. Beta of debt is assumed, as throughout the paper, to be 0.175 . Book values of debt are obtained from COMPUSTAT. Operating asset Beta Correct is the Operation Asset Beta when correctly accounting for pension value and risk, Operating Asset Beta Error 1 is the Operating Asset Beta, ignoring pension plan altogether, and Operating Asset Beta Error 2 is the Operating Asset Beta, counting pension value but mis-representing pension risk. 
Table 1.2. Estimated Equity and Operating Asset Betas for 2001

\begin{tabular}{|c|c|c|c|c|c|c|}
\hline Company & Equity Beta & $\begin{array}{r}\text { Operating } \\
\text { Asset Beta } \\
\text { Correct }\end{array}$ & $\begin{array}{r}\text { Operating } \\
\text { Asset Beta } \\
\text { Error1 }\end{array}$ & \%overestimate & $\begin{array}{r}\text { Operating } \\
\text { Asset Beta } \\
\text { Error2 }\end{array}$ & \%overestimate \\
\hline BOEING & 0.69 & 0.16 & 0.54 & $250 \%$ & 0.55 & $256 \%$ \\
\hline $\begin{array}{l}\text { DU PONT } \\
\text { EASTMAN }\end{array}$ & 0.71 & 0.45 & 0.63 & $41 \%$ & 0.63 & $39 \%$ \\
\hline KODAK & 0.87 & 0.35 & 0.68 & $93 \%$ & 0.70 & $99 \%$ \\
\hline TEXTRON & 0.73 & 0.26 & 0.43 & $64 \%$ & 0.44 & $69 \%$ \\
\hline
\end{tabular}

Note: Pension Asset and Pension Liability and Market Cap information are as estimated based on the Global Equity Research Report published by UBS Warburg, September 19, 2002. Beta of equity are estimated using CAPM, using data on three year monthly stock returns, obtained from CRSP, and by using the value-weighted return on all stocks on NYSE/AMEX/NADDAQ as the proxy for the market. Beta of debt is assumed, as throughout the paper, to be 0.175 . Book values of debt are obtained from COMPUSTAT. Operating asset Beta Correct is the Operation Asset Beta when correctly accounting for pension value and risk, Operating Asset Beta Error 1 is the Operating Asset Beta, ignoring pension plan altogether, and Operating Asset Beta Error 2 is the Operating Asset Beta, counting pension value but mis-representing pension risk. 
Table 2 Pension Asset Categories as reported in Form 5500, and Assumed Beta Risk

\begin{tabular}{llr}
\hline \hline \multirow{2}{*}{ Pension Asset Categories } & Assumed \\
Equities & preferred stock & 1.000 \\
& common stock & 1.000 \\
& joint venture & 1.000 \\
& employer securities & 1.000 \\
& interest in registered investment companies & 1.000 \\
Bonds & governmental bonds & 0.175 \\
& corporate debt instruments (preferred and other) & 0.175 \\
& loans secured by mortgages (residential and & 0.175 \\
& commercial) & 0.175 \\
& loans to participants & 0.175 \\
& other loans & 0.006 \\
cash & non-interest bearing cash & 0.006 \\
& certificates of deposit (CD) & 0.150 \\
Real Estate & income producing real estate & 0.150 \\
& non-income producing real estate & \\
\hline \hline
\end{tabular}


Table 3: relation between pension risk and firm risk

\begin{tabular}{rrrr}
\hline \hline measure of distress & $(1)$ & $(2)$ & $(3)$ \\
intercept & & & 0.9108 \\
& 0.8730 & 0.8733 & $(8.9652)$ \\
pension risk & $(9.7376)$ & $(9.8763)$ & 1.9601 \\
& 2.0117 & 1.699 & $(4.1523)$ \\
Adjusted $\mathrm{R}^{2}$ & $(5.7812)$ & $(4.6538)$ & 0.0134 \\
\hline \hline
\end{tabular}

Note: This table reports regression results using ERISA form 5500 filing data from 1993 to 1998.

The regression being run is: $\beta_{E+D}=\alpha+\gamma \beta_{\text {Pension }}+\varepsilon$

All results are estimated with company betas estimated using market model with one lagged term, and with the end-of-year pension data. Three measures of distress are tried: (1) return on investment; (2) financial leverage; (3) book-market ratio. T-statistics are reported in parenthesis and under each regression coefficients; 
Table 4 List of control variables

\begin{tabular}{|c|c|}
\hline Variable Description & Calculation using COMPUSTAT Codes or Other Source \\
\hline market share by value & calculated using market value and 3 digit SIC code \\
\hline market share by sales & calculated using total sales and the 3 digit SIC code \\
\hline capital intensiveness & DATA4/DATA6 \\
\hline cash position & DATA1/DATA6 \\
\hline financial leverage & Debt/DATA6 \\
\hline growth rate & Log(DATA6/DATA6_lag) \\
\hline liquidity & DATA4/DATA5 \\
\hline return on investment & DATA172 / DATA6 \\
\hline firm size & $\log (\mathrm{DATA} 6)$ \\
\hline concentration index & calculated using market value and the 3 digit SIC code \\
\hline advertisement & DATA45/DATA6, missing value is taken to be 0 \\
\hline \multicolumn{2}{|c|}{ Research and development DATA46/DATA6, missing value is taken to be 0} \\
\hline
\end{tabular}


Table 5: relation between pension risk and firm risk: simple test

\begin{tabular}{lr}
\hline \hline & \\
Intercept & -0.3378 \\
& $(-1.0238)$ \\
pension risk & 1.1188 \\
& $(3.7825)$ \\
Adjusted R-squared & 0.2291 \\
\end{tabular}

Note: This table reports regression results using ERISA form 5500 filing data from 1993 to 1998 . The regression being run is: $\beta_{E+D}=\alpha+\gamma \beta_{\text {Pension }}+\lambda$ control $+\varepsilon$

All results are estimated with company betas estimated using market model with one lagged term, and with the end-of-year pension data. The following control variables are included but their coefficients are not reported: market share by value, market share by sales, capital intensiveness, cash position, financial leverage, growth rate, liquidity, return on investment, firm size, concentration index, advertisement, research and development. The regression are run for firms that are not in distress, proxied by the book-to-market ratio.T-statistics are reported in parenthesis and under each regression coefficients; 
Table 6: relation between pension risk and firm risk: distressed firms only

Intercept

0.3359

Pension Risk

(3.7837)

0.1133

$(0.1932)$

Adjusted R-squared

0.2031

Note: This table reports regression results using ERISA form 5500 filing data from 1993 to

1998. The regression being run is: $\beta_{E+D}=\alpha+\gamma \beta_{\text {Pension }}+\lambda$ control $+\varepsilon$

All results are estimated with company betas estimated using market model with one lagged term, and with the end-of-year pension data. The following control variables are included but not reported: market share by value, market share by sales, capital intensiveness, cash position, financial leverage, growth rate, liquidity, return on investment, firm size, concentration index, advertisement, research and development. The regression are run for firms that are not in distress, proxied by the book-to-market ratio.T-statistics are reported in parenthesis and under each regression coefficients; 
Table 7: test with both distressed and non-distressed firms

\begin{tabular}{lrr}
\hline \hline & $(1)$ : without control & (2): with control \\
Intercept & 0.8506 & -0.3015 \\
& $(9.7832)$ & $(-1.0132)$ \\
Pension Risk & 1.6507 & 1.0192 \\
& $(3.8982)$ & $(3.5237)$ \\
Adjusted R-squared & 0.0109 & 0.2351 \\
& & \\
\hline \hline
\end{tabular}

Note: This table reports regression results using ERISA form 5500 filing data from 1993 to

1998. The regression being run is: $\beta_{E+D}=\alpha+\gamma \beta_{\text {Pension }}+\lambda$ control $+\varepsilon$

Note: All results are estimated with company betas estimated using market model with one lagged term, and with the end-of-year pension data. The following control variables are included in the second column, but not reported: market share by value, market share by sales, capital intensiveness, cash position, financial leverage, growth rate, liquidity, return on investment, firm size, concentration index, advertisement, research and development. The regressions are run for firms that are not in distress, proxied by the book-to-market ratio. Tstatistics are reported in parenthesis and under each regression coefficients; 
Table 8: filtered test results

\begin{tabular}{lrr}
\hline \hline filter used & beta_PA*PA/TA $>0.02$ & PA/TA $>0.02$ \\
Intercept & -0.4698 & -0.3778 \\
& $(-1.2138)$ & $(-1.0253)$ \\
Pension Risk & 1.7806 & 1.3519 \\
& $(2.1372)$ & $(3.9832)$ \\
Adjusted R-squared & 0.2575 & 0.2277 \\
\end{tabular}

Note: This table reports regression results using ERISA form 5500 filing data from 1993 to 1998. The regression being run is: $\beta_{E+D}=\alpha+\gamma \beta_{\text {Pension }}+\lambda$ control $+\varepsilon$

All results are estimated with company betas estimated using market model with one lagged term, and with the end-of-year pension data. The following control variables are included but not reported: market share by value, market share by sales, capital intensiveness, cash position, financial leverage, growth rate, liquidity, return on investment, firm size, concentration index, advertisement, research and development. The regression are run for firms that are not in distress, proxied by the book-to-market ratio.T-statistics are reported in parenthesis and under each regression coefficients; 


\section{Appendix A. Issues with the data}

Despite the amount of different data files that were eventually incorporated, there is quite a bit of homogeneity between the data sources. The control variables, the pension liabilities data all came from COMPUSTAT. These information are released to the general public through the $10 \mathrm{~K}$ form, thus market should be able to incorporate these information pretty rapidly.

Tracing the first date that firm pension plan investment is released is a bit tricky. While corporate insiders know the pension asset allocation decision pretty rapidly, the market may or may not immediately get that information. The FORM 5500 data is released by ERISA with roughly a two-year lag. However, part of the pension funds asset allocation information might be available to the general public sooner, especially if these pension funds are large and selfmanaged: funds are typically required by various other regulations to reveal certain information to the public. For example, SEC regulation 13F requires institutions (including pension funds) to report quarterly holdings of securities when the total holdings are above \$100 million. In any case, the lack of timely information in pension asset allocation decisions might not be as severe a problem as it appears: pension asset allocation decisions empirically don't change much over time, for a specific firm. A simple correlation analysis reveals that the first order auto-correlation between pension risk over time is more than 0.95 . Thus, knowing the past asset allocation decisions of a firm will generally give one a very good idea about its current asset allocation decisions.

Research and Development and Advertisement both had many missing values. In our main analysis, missing values were taken to be 0 . Alternatively, adding a dummy for missing variables don’t qualitatively change any of our results.

We combine the CRSP returns data and the COMPUSTAT data through the merged COMPUSTAT/CRSP database file, by merging PERMNO and GVKEY (the unique identifiers in CRSP and COMPUSTAT respectively). The pension asset data from Form 5500 is matched with the COMPUSTAT through matching the Employment Identification Number (EIN). This proved better than CUSIP (there are a number of redundant CUSIPs), and a test of the first 100 
data points showed that there was remarkably high success rate in the combination (no incorrect matches - although there were a handful of companies that had merged and had different names in one data set or the other). The only problem is, this method works to the extent that firms have a unique EIN. Often, but not always, when a firm is purchased by another plan, the acquired firms keep their old EIN as all the employment taxes are filed by the subsidiary. Thus larger firm and more acquisitive firms present a problem. To our knowledge, the only way to partially address this is to search the names of the sponsors, and this works only if it isn't an unrelated name of a subsidiary ${ }^{20}$.

The beta of pension asset is calculated by assigning different asset types to broad categories (real estate, cash, bonds, and equities), and assigning beta for each asset types. If a company had more than one defined benefit pension plan, the assets in the multiple plans were summed up. Admittedly, if we could get more accurate estimate of the exact holdings of pension assets, and/or more precise measures of each of the assets' beta, that would likely improve our test results.

\footnotetext{
${ }^{20}$ We thank Mitchell Peterson for sharing with us his experience on merging pension data with COMPUSTAT data.
} 


\section{Appendix B. Derivation of Equations in Section 2.}

1. Proof of Equation (3):

If both the value and the risk of pension are ignored, then the estimated operating asset risk becomes

$$
\hat{\hat{\beta}}_{O A}=\frac{D}{E+D} \beta_{D}+\frac{E}{E+D} \beta_{E}
$$

If we define $\hat{O} A=E+D$ as the "pseudo operating asset", then, from accounting identity, $\hat{O A}=O A+S$, and

$$
\hat{\hat{\beta}}_{O A}=\frac{D}{\hat{O} A} \beta_{D}+\frac{E}{\hat{O} A} \beta_{E}=\frac{1}{1+L} \beta_{E}+\frac{1}{1+L} \beta_{D}
$$

Thus we have:

$$
\begin{aligned}
& \beta_{O A}=\frac{E}{O A} \beta_{E}+\frac{D}{O A} \beta_{D}-\left[\frac{P A}{O A} \beta_{P A}-\frac{P L}{O A} \beta_{P L}\right] \\
& =\frac{O A+S}{O A} \hat{\hat{\beta}}_{O A}-\frac{P A}{O A}\left(\beta_{P A}-\beta_{P L}\right)-\frac{\beta_{P L}}{O A} S \\
& =\hat{\hat{\beta}}_{O A}+\frac{S}{O A}\left(\hat{\hat{\beta}}_{O A}-\beta_{P L}\right)-\frac{P A}{O A}\left(\beta_{P A}-\beta_{P L}\right)
\end{aligned}
$$

The estimation error, defined as $\hat{\hat{\varepsilon}}_{O A}=\hat{\hat{\beta}}_{O A}-\beta_{O A}$, is given by:

$$
\begin{aligned}
& \hat{\hat{\varepsilon}}_{O A}=\hat{\hat{\beta}}_{O A}-\beta_{O A} \\
& =-\frac{S}{O A}\left(\hat{\hat{\beta}}_{O A}-\beta_{P L}\right)+\frac{P A}{O A}\left(\beta_{P A}-\beta_{P L}\right) \\
& =\frac{P A}{O A}\left(\beta_{P A}-\beta_{P L}\right)-\frac{S}{O A}\left[\frac{1}{1+L}\left(\beta_{E}-\beta_{D}\right)-\left(\beta_{P L}-\beta_{D}\right)\right]
\end{aligned}
$$

Plug in the definition of $\hat{\hat{\varepsilon}}_{O A}$, we have $\hat{\hat{\varepsilon}}_{O A}=\frac{P A}{O A}\left(\beta_{P A}-\beta_{P L}\right)-\frac{S}{O A}\left[\beta_{O A}-\beta_{P L}+\hat{\hat{\varepsilon}}_{O A}\right]$. Re-arranging, we have:

$$
\hat{\hat{\varepsilon}}_{O A}=\frac{P A}{\hat{O A}}\left(\beta_{P A}-\beta_{P L}\right)-\frac{S}{\hat{O A}}\left[\beta_{O A}-\beta_{P L}\right]
$$

Thus one sufficient condition for $\hat{\hat{\varepsilon}}_{O A} \geq 0$ is $\beta_{P A} \geq \beta_{P L}, \beta_{O A} \geq \beta_{P L}$, and, $s \leq 0$

QED. 
Proof of Equation (5):

From the accounting identity, $\mathrm{OA}+\mathrm{S}=\mathrm{E}+\mathrm{D}$, we have,

$\mathrm{OA}=\mathrm{E}+(\mathrm{D}-\mathrm{S})$

i.e., pension deficit is treated as a negative debt.

In terms of risk calculation, we have the miscalculated operating asset beta satisfies:

$\hat{\beta}_{O A} O A=\beta_{E} E+\beta_{D}(D-S)$

Thus the bias in the beta is given by:

$$
\begin{aligned}
& \hat{\varepsilon}_{O A}=\hat{\beta}_{O A}-\beta_{O A} \\
& =\beta_{E} \frac{E}{O A}+\beta_{D} \frac{(D-S)}{O A}-\frac{E}{O A} \beta_{E}-\frac{D}{O A} \beta_{D}+\left[\frac{P A}{O A} \beta_{P A}-\frac{P L}{O A} \beta_{P L}\right] \\
& =\frac{P L-P A}{O A} \beta_{D}+\frac{P A}{O A} \beta_{P A}-\frac{P L}{O A} \beta_{P L} \\
& =\frac{P L}{O A}\left(\beta_{D}-\beta_{P L}\right)+\frac{P A}{O A}\left(\beta_{P A}-\beta_{D}\right)
\end{aligned}
$$

QED. 


\section{Appendix C. Complete Regression Results for tables 5, 6, 7 and 8}

Complete Regression results for Table 5:

Table 5: relation between pension risk and firm risk: simple test

\begin{tabular}{|c|c|c|c|}
\hline measure of distress & return on investments & financial leverage & book-market ratio \\
\hline \multirow[t]{2}{*}{ Intercept } & -0.7952 & -0.3622 & -0.3378 \\
\hline & -2.9235 & -0.8926 & -1.0238 \\
\hline \multirow[t]{2}{*}{ Gamma } & 1.0416 & 1.0193 & 1.1188 \\
\hline & 2.9398 & 3.2879 & 3.7825 \\
\hline \multirow[t]{2}{*}{ market share by value } & 8.8420 & 10.7988 & 12.8760 \\
\hline & 1.2326 & 1.7299 & 1.7414 \\
\hline \multirow[t]{2}{*}{ market share by sales } & -7.4401 & -8.7870 & -11.4165 \\
\hline & -0.8755 & -1.1598 & -1.3662 \\
\hline \multirow[t]{2}{*}{ capital intensiveness } & 0.3015 & 0.4115 & 0.4017 \\
\hline & 1.2566 & 1.0877 & 1.2693 \\
\hline \multirow[t]{2}{*}{ cash position } & -0.2083 & 0.2686 & 0.5398 \\
\hline & -0.2710 & 0.4395 & 1.1857 \\
\hline \multirow[t]{2}{*}{ financial leverage } & -0.0622 & -0.4140 & -0.0133 \\
\hline & -0.2244 & -0.5403 & -0.0478 \\
\hline \multirow[t]{2}{*}{ growth rate } & 0.2633 & 0.1517 & -0.0598 \\
\hline & 0.7492 & 0.5050 & -0.1757 \\
\hline \multirow[t]{2}{*}{ liquidity } & -0.0248 & -0.0436 & -0.0445 \\
\hline & -1.1109 & -1.1748 & -1.4243 \\
\hline \multirow[t]{2}{*}{ return on investment } & 9.6204 & 5.1357 & 3.8693 \\
\hline & 6.4126 & 2.3879 & 4.9011 \\
\hline \multirow[t]{2}{*}{ firm size } & 0.1217 & 0.1149 & 0.1019 \\
\hline & 2.8725 & 2.7580 & 1.8682 \\
\hline \multirow[t]{2}{*}{ concentration index } & 0.6260 & 0.8150 & 0.9069 \\
\hline & 0.4512 & 0.5232 & 0.5495 \\
\hline \multirow[t]{2}{*}{ advertisement } & 2.0965 & 2.2420 & 2.1677 \\
\hline & 1.0060 & 0.7462 & 1.0245 \\
\hline \multirow[t]{2}{*}{ research and devel } & 8.0776 & 8.6934 & 8.7364 \\
\hline & 1.5815 & 1.8014 & 1.9204 \\
\hline Adjusted R-squared & 0.3100 & 0.2686 & 0.2291 \\
\hline
\end{tabular}

Note: All results are estimated with company betas estimated using market model with one lagged term, and with the end-of-year pension data. T-statistics are reported under each regression coefficients; 
Complete Regression Results for Table 6:

Table 6: relation between pension risk and firm risk: distressed firms only

\begin{tabular}{|c|c|c|c|}
\hline measure of distress & return on investments & financial leverage & book-market ratic \\
\hline \multirow[t]{2}{*}{ Intercept } & 0.2319 & 0.7395 & 0.3359 \\
\hline & 0.6590 & 1.7873 & 3.7837 \\
\hline \multirow[t]{2}{*}{ Gamma } & -0.6708 & -0.1679 & 0.1133 \\
\hline & -0.7805 & -0.0897 & 0.1932 \\
\hline \multirow[t]{2}{*}{ market share by value } & 5.1595 & 14.1931 & 0.1050 \\
\hline & 1.0923 & 2.0565 & 0.0117 \\
\hline \multirow[t]{2}{*}{ market share by sales } & -4.7247 & -9.6382 & 3.0802 \\
\hline & -0.8849 & -1.3145 & 0.9460 \\
\hline \multirow[t]{2}{*}{ capital intensiveness } & -0.0490 & -0.0265 & 0.1271 \\
\hline & -0.0829 & -0.0740 & 0.5332 \\
\hline \multirow[t]{2}{*}{ cash position } & 0.5619 & -1.2075 & 0.2867 \\
\hline & 0.5017 & -1.2898 & 0.4263 \\
\hline \multirow[t]{2}{*}{ financial leverage } & 0.0498 & 0.0616 & -0.0995 \\
\hline & 0.1232 & 0.0614 & -0.2932 \\
\hline \multirow[t]{2}{*}{ growth rate } & -0.0896 & -0.2691 & 0.1077 \\
\hline & -0.2062 & -1.0461 & 0.3293 \\
\hline \multirow[t]{2}{*}{ liquidity } & -0.0041 & -0.0415 & -0.0318 \\
\hline & -0.0424 & -0.9517 & -1.0174 \\
\hline \multirow[t]{2}{*}{ return on investment } & 0.1402 & 0.9626 & 0.0602 \\
\hline & 0.1687 & 0.8215 & 0.0866 \\
\hline \multirow[t]{2}{*}{ firm size } & 0.0437 & 0.0013 & -0.0075 \\
\hline & 0.3699 & 0.0194 & -0.2473 \\
\hline \multirow[t]{2}{*}{ concentration index } & 0.1241 & -1.1822 & -0.3516 \\
\hline & 0.0301 & -0.2903 & -0.7573 \\
\hline \multirow[t]{2}{*}{ advertisement } & -2.0094 & 0.8650 & -1.5842 \\
\hline & -0.7099 & 0.4698 & -0.8687 \\
\hline \multirow[t]{2}{*}{ research and devel } & 5.3577 & 5.2189 & -0.3865 \\
\hline & 1.0959 & 1.2303 & -0.1976 \\
\hline Adjusted R-squared & 0.2578 & 0.2567 & 0.2031 \\
\hline
\end{tabular}

Note: All results are estimated with company betas estimated using market model with one lagged term, and with the end-of-year pension data. T-statistics are reported under each regression coefficients; 
Complete Regression Results For Table 7:

Table 7: test with both distressed and non-distressed firms

\begin{tabular}{lrr}
\hline \hline Intercept & 0.8506 & -0.3015 \\
Gamma & 9.7832 & -1.0132 \\
& 1.6507 & 1.0192 \\
market share by value & 3.8982 & 3.5237 \\
market share by sales & & 12.2483 \\
& & 2.0389 \\
capital intensiveness & & -9.6723 \\
cash position & & -1.3450 \\
financial leverage & 0.4059 \\
growth rate & & 1.7938 \\
liquidity & & 0.5403 \\
return on investment & 1.1372 \\
firm size & & -0.0833 \\
concentration index & -0.2325 \\
advertisement & -0.0176 \\
research and devel & -0.0695 \\
Adjusted R-squared & -0.0456 \\
& & -1.6812 \\
\hline \hline & & 3.4136 \\
& & 2.7642 \\
& & 0.0993 \\
& & 1.9959 \\
& & 0.7627 \\
& & 0.4440 \\
& & 2.2807 \\
& & 1.1027 \\
& & 8.7918 \\
& & 1.9139 \\
& & 0.2351 \\
& \\
\hline
\end{tabular}

Note: All results are estimated with company betas estimated using market model with one lagged term, and with the end-of-year pension data. T-statistics are reported under each regression coefficients; 
Complete Regression Results For Table 8:

Table 8: filtered test results

\begin{tabular}{lrr}
\hline \hline filter used & beta_PA*PA/TA>0.02 & PA/TA>0.02 \\
Intercept & -0.4698 & -0.3778 \\
Gamma & -1.2138 & -1.0253 \\
& 1.7806 & 1.3519 \\
market share by value & 2.1372 & 3.9832 \\
& 12.2776 & 13.0770 \\
market share by sales & 2.1581 & 2.0683 \\
& -6.8838 & -12.2163 \\
capital intensiveness & -0.7549 & -1.4842 \\
& -0.0158 & 0.3165 \\
cash position & -0.0308 & 0.8110 \\
financial leverage & 1.5404 & 0.7277 \\
growth rate & 0.8461 & 1.2188 \\
liquidity & 0.3047 & -0.0203 \\
& 0.7244 & -0.0751 \\
return on investment & -0.0511 & -0.0562 \\
firm size & -0.0806 & -0.1901 \\
& -0.0585 & -0.0510 \\
concentration index & -0.7900 & -1.3850 \\
advertisement & 5.0331 & 3.8123 \\
research and devel & 4.4008 & 4.6131 \\
Adjusted R-squared & 0.0922 & 0.1067 \\
& 1.2762 & 1.6245 \\
\hline \hline & 1.9302 & 1.9984 \\
& 0.8029 & 0.9116 \\
& 1.6628 & 2.0816 \\
& 0.6059 & 1.1534 \\
& 8.0885 & 8.4191 \\
& 1.7966 & 1.9554 \\
& 0.2575 & 0.2277 \\
& & \\
\hline
\end{tabular}

Note: All results are estimated with company betas estimated using market model with one lagged term, and with the end-of-year pension data. T-statistics are reported under each regression coefficients; 